\title{
A False Powder-post Beetle, Xylopsocus capucinus (Fabridius) (Insecta: Coleoptera: Bostrichidae) ${ }^{1}$
}

R. E. Woodruff, E. J. Gerberg and T. J. Spilman²

\section{Introduction}

Xylopsocus capucinus (Fabricius) has previously been intercepted at ports of entry into the U.S. on many occasions in a wide variety of plant materials. However, Fisher (1950) stated that it "has not become established in the United States." On 14 March 1978, specimens were collected from cassava branches at Homestead, Florida, by J. Peña, and subsequent surveys indicate that the species is definitely established as a part of the Florida fauna.

\section{Distribution}

Occurs throughout most of the tropical areas of the world. Lesne (1901:633) listed it from the Indomalayan area to the Madagascaran region with specific locations as follows: Madagascar, Comores, Seychelles, Reunion, Mauritius, Sikkim, Coromandel, Nilghiri, Sri Lanka, Myanmar, Vietnam, Laos, Cambodia, Nicobar, Sumatra, Java, Sumbawa, Borneo, Celebes, Philippines, Ternate, Batjan, Ceram, Amboine, Kei, Arou, New Guinea,
Trobriand, Woodlark, d'Entrecasteaux, Louisiade, New Hebrides, Espiritu-Santo, New Caledonia, Sierra Leone, South America (Guiana and eastern Brazil).

Fisher (1950:141) listed the following records: India, Ceylon, China, Siam, Indochina, Myanmar, Formosa, Philippines, nearly all Malaysian and Melanesian Islands, and Madagascar. He listed it as introduced into the eastern and western coasts of Africa, Guiana, Venezuela, Trinidad, and Brazil.

In Florida, it is presently known only from the area around Homestead (Dade County).

\section{Description}

Adult: Length 3 to $5.5 \mathrm{~mm}$; width 1.4 to $1.7 \mathrm{~mm}$. Shape cylindrical and similar in general appearance to other common species of the family Bostrichidae found in Florida. Because of this similarity, field identification is impractical, and specimens should be submitted to taxonomists for identification.

1. This document is EENY-179 (originally published as DPI Entomology Circular 195), one of the Featured Creatures series of the Entomology and Nematology Department, Cooperative Extension Service, Institute of Food and Agricultural Sciences, University of Florida. Published: December 2000. This document is also available on Featured Creatures Website at http://creatures.ifas.ufl.edu. Please visit the EDIS Website at http://edis.ifas.ufl.edu Additional information on these organisms, including many color photographs, is available at the Entomology and Nematology Department website at http://entnemdept.ifas.ufl.edu/.

2. R.E. Woodruff, Florida Department of Agriculture and Consumer Services, Division of Plant Industry; E.J. Gerberg, Entomology and Nematology Department, University of Florida; and T.J. Spilman, Florida Department of Agriculture and Consumer Services, Division of Plant Industry, Gainesville, FL.

The Institute of Food and Agricultural Sciences (IFAS) is an Equal Employment Opportunity - Affirmative Action Employer authorized to provide research, educational information and other services only to individuals and institutions that function without regard to race, creed, color, religion, age, disability, sex, sexual orientation, marital status, national origin, political opinions or affiliations. For information on obtaining other extension publications, contact your county Cooperative Extension Service office. Florida Cooperative Extension Service/Institute of Food and Agricultural Sciences / University of Florida / Larry R. Arrington, Interim Dean 


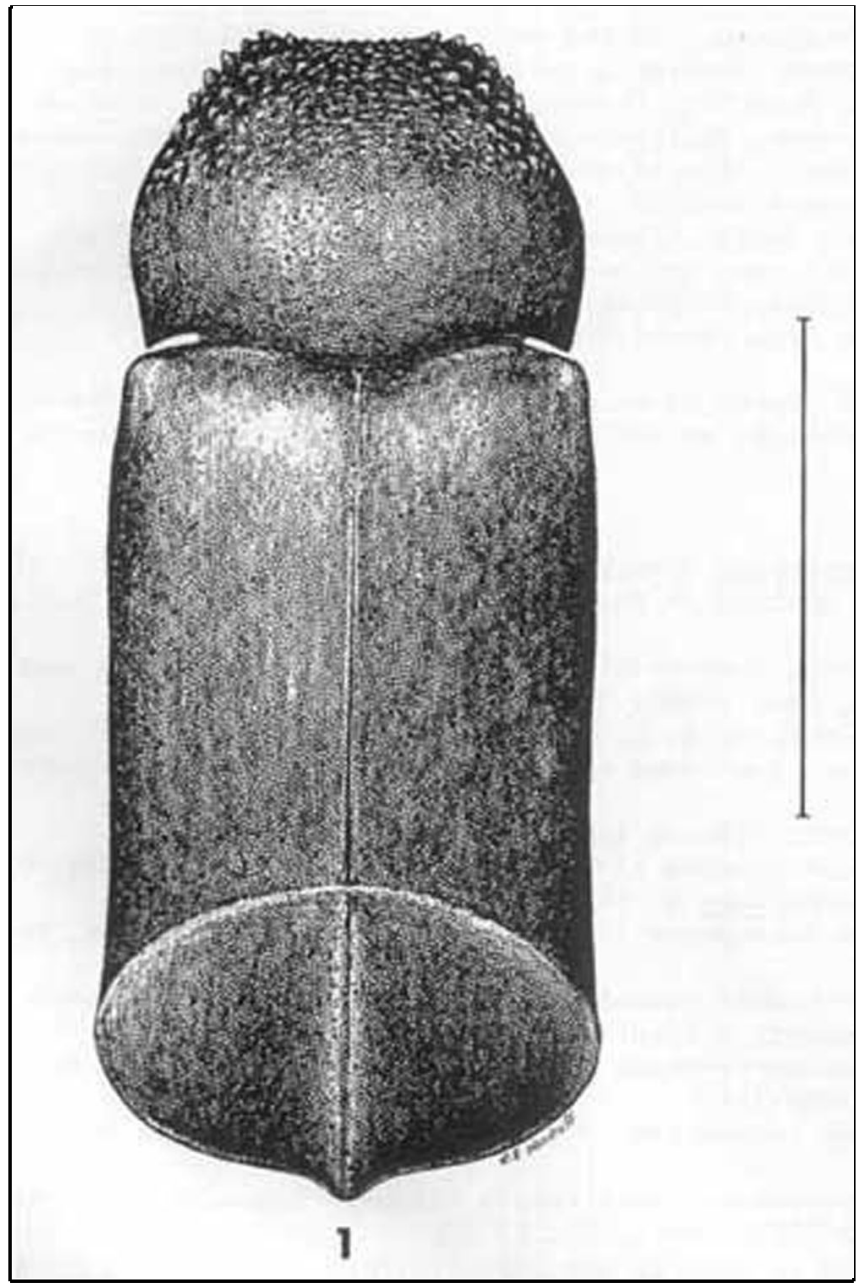

Figure 1. Dorsal view of adult Xylopsocus capucinus (Fabricius), a false powder-post beetle. Line equals $2 \mathrm{~mm}$. Credits: Division of Plant Industry

The body color is black or reddish (particularly the elytra, venter, antennae, and palpi). The apical elytral declivity is abruptly, obliquely deflexed, flattened, without tubercles or callosities. The lateral margins of the declivity are strongly elevated, crenulate toward top, and completely enclose the declivity. This arrangement is distinctive from other U.S. Bostrichidae.

The larva has been described and illustrated by Gardner (1933).

\section{Biology}

Beeson and Bhatia (1937) indicated that it was not common in India, but it emerged mainly between May and November without marked peaks of abundance. The life cycle there is apparently annual but may extend to two years, with stragglers in the

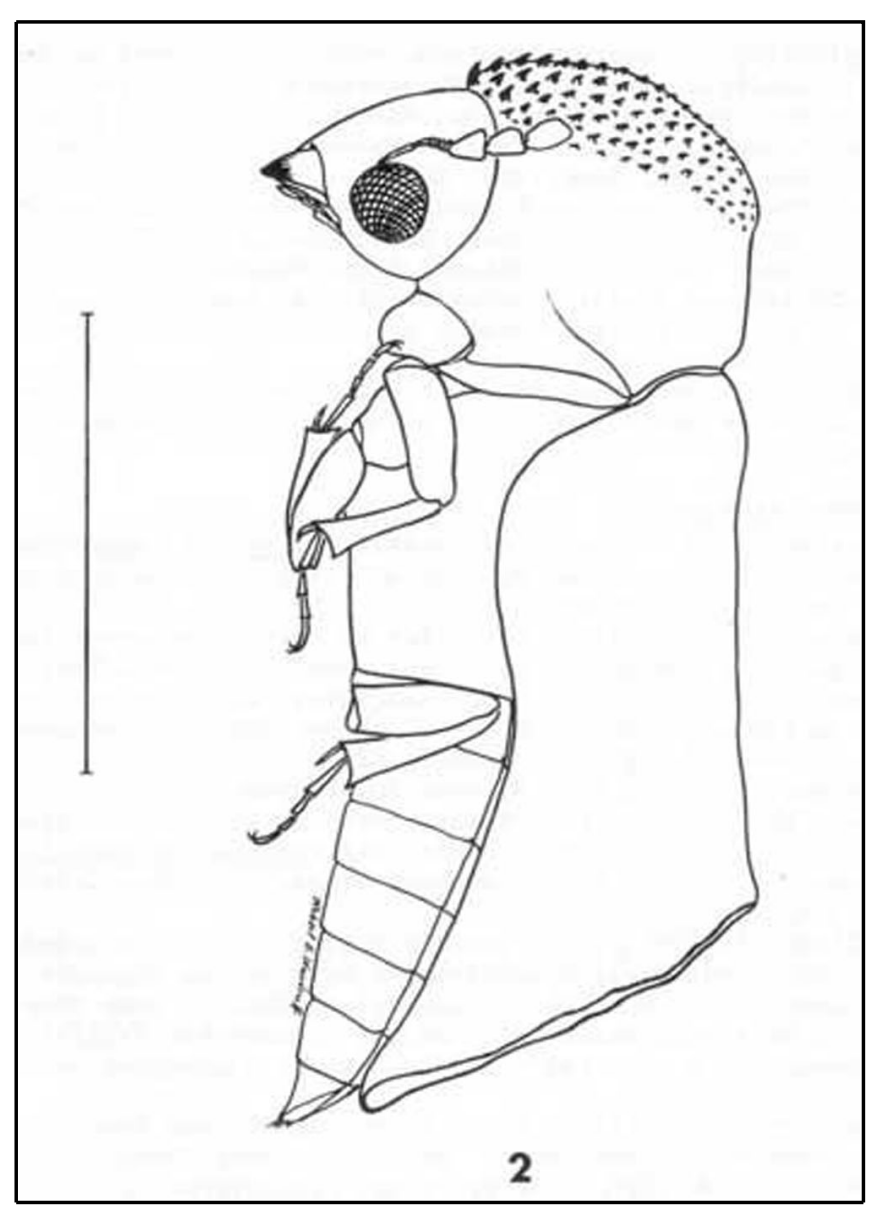

Figure 2. Lateral view of adult Xylopsocus capucinus (Fabricius), a false powder-post beetle. Line equals $2 \mathrm{~mm}$. Credits: Division of Plant Industry

third year. Additional biological data were given by Miller (1934), who stated that the life cycle is eight weeks when the larva feeds in Derris roots. He also recorded a reduviid bug (Peregrinator biannulipes Montr. \& Sign.) as a predator on $X$. capucinus.

Most damage appears to be caused to lumber or to plants already damaged by lightning, cold, or other insect injury. Kalshoven (1963b) listed it from piles of teak poles where the sapwood layer became honeycombed throughout. Most references mention dry branches and stems being most often infested. Marin Acosta (1975) listed it in unhealthy avocado trees and in stems of grape where its presence was shown by little masses of gum (in rolled strips) in their openings.

\section{Hosts}

According to Fisher (1950), Lesne (1924) recorded this species living in the wood of Morus 
alba L. and in trunks of "Kimoungoue" in east Africa, in bamboo, litchi (Litchi chinensis Sonn.), and in grape (Vitis sp.) in Brazil. Miller (1934) recorded it attacking piquia (Caryocar villosum Pers.), rambutun (Nephelium lappaceum L.), rubber (Hevea brasiliensis (Willd. ex A. Juss) Muell. Arg.), Dipterocarpus sp., Derris sp., guava (Psidium guajava L.), Casuarina equisetifolia J.R. Forst. \& G. Forst., Syzygium malaccensis (L.) Merrill \& L.M. Perry, cinnamon (Cinnamomum zeylanicum Blume), Indigofera anil L., cashew nut (Anacardium occidentale L.), durian (Durio zibethinus J. Murr.), Tephrosia candida DC., Gardenia jasminoides Ellis, tamarind (Tamarindus indica L.), Hibiscus rosa-sinensis L., and mango (Mangifera indica L.). Beeson and Bhatia (1937) reported it as also attacking Artocarpus hirsutus Lam., Ficus sp., Mallotus philippiensis Muell. Arg., Delonix elata (L.) Gamble, Santalum album L., Shorea robusta Gaertn.f., Sindora wallichii Benth., Swietenia mahagoni (L.) Jacq., Tectona grandis L.f., Terminalia myriocarpa Heurck \& Muell. Arg., and Vitex negunto L. Guagliumi (1967) recorded it in avocado seed and stems and branches of cotopriz (Talisia oliviformis Radlk.).

The Florida host has only been cassava, in dry branches (presumably cold killed).

\section{Management}

As presently known, the species does not appear to be a serious economic pest. Infested cassava branches were destroyed by burning.

For more information see Insect Management Guide for Powderpost Beetles (http://edis.ifas.ufl.edu/IG119).

\section{Selected References}

Anonymous. 1978. A bostrichid beetle (Xylopsocus capucinus (Fabricius)). Coop. Plant Pest Rept. 3: 177.

Beeson, C.F.C., and B.M. Bhatia. 1937. On the biology of the Bostrychidae (Coleoptera). Indian Forest Rec. 2: 223-320.
Blackwelder, R.E. 1945. Checklist of the coleopterous insects of Mexico, Central America, the West Indies, and South America. U.S. Nat. Mus. Bull. 185, Part 3: 400.

d'Araujo e Silva, A.G., C.R. Gonçalves, D.M. Galvao, A.J.L. Gonçalves, J. Gomes, M. do N. Silva, and L. de Simoni. 1968. Quarto catalogo dos insectos que vivem nas plantas do Brasil seus parasites e predadores. Pt. 2. Vol. 1: xiv $+622 \mathrm{p}$.

Fabricius, J.C. 1781. Species insectorum. 1: 1-552; Kilonii (Apate capucinus p. 62).

Fisher, W.S. 1950. A revision of the North American species of beetles belonging to the family Bostrichidae. USDA Misc. Publ. 698: 1-157 (Xylopsocus capucinus p. 140-141).

Gardner, J.C.M. 1933. Immature stages of Indian Coleoptera (13) (Bostrychidae). Indian For. Res., Ent. Ser. 18: 1-19.

Guagliumi, P. 1966 [1967]. Insetti e arachnidi delle piante comuni del Venezuela segnalati nel periodo 1938-1963. Relazioni e monographie agrarie subtropicale e tropicali (n.s.) 68: i- xix, 1-391.

Kalshoven, L.G.E. 1963a. Ecological data on some Neotropical Scolytidae, Platypodidae, and Bostrychidae (Coleoptera) mainly of Surinam. Beaufortia 9: 232-240.

Kalshoven, L.G.E. 1963b. Notes on the biology of Indonesian Bostrychidae (Coleoptera). Ent. Berichten 23: 242-257.

Kingsolver, J.M. 1971. A key to the genera and species of Bostrichidae commonly intercepted in USDA plant quarantine inspections. Agr. Quar. Insp. Memo (USDA) 697: 1- 11.

Lesne, P. 1900 [1901]. Revision des Coleopteres de la famille des Bostrychides. 4th Mem. Ann. Soc. Ent. France 69: 473-639.

Marin Acosta, J.C. 1975. Plagas de insectos en algunos frutales de importancia economica en Venezuela. Bol. Techn. (Publ. Fondo de Desarrollo Fruticola) 3: 1-73. 
Miller, N.C.E. 1934. Coleopterous pests of stored

Derris in Malaya. Dept. Agr. Straits Settlements

Federated Malay States, Sci. Ser. 14: 1-34.

Spilman, T.J. 1971. Bredin-Archbold-

Smithsonian biological survey of Dominica:

Bostrichidae, Inopeplidae, Lagriidae, Lyctidae, Lymexylonidae, Melandryidae, Monommidae, Rhipiceridae, and Rhipiphoridae (Coleoptera). Smithsonian Contr. Zool. 70: 1-10.

Stebbing, E.P. 1914. Indian forest insects of economic importance. Coleoptera. London, Eyre \& Spottiswoode, Ltd. 648 p. 